\title{
Tribute to Robert D. Tollison
}

\author{
James C. Miller III ${ }^{1}$
}

Received: 31 December 2016/Accepted: 31 January 2017/Published online: 16 February 2017

(C) Springer Science+Business Media New York 2017

It has become fashionable to sum up the passing of a great one by saying they will be missed. Saying that about Bob Tollison would understate the magnitude and endurance of Bob's legacy. Bob is all around us-his ideas and, especially, the colleagues and students he nurtured over the years.

From even a casual perusal of Bob's curriculum vitae, one comes away with conviction that here's an economist who lived a full life. First, his research interests. They covered a gamut of issues in public choice, both theoretical and empirical. In application, they dealt with a variety of institutions-legislatures, regulatory agencies, voluntary associations, and governance. Does Congress perform well, and if not, why not? Bob had answers. Do regulatory agencies serve private interests or public interests? Can their performance be improved, and if so how? Does the National Collegiate Athletic Association serve the interests of college and professional sports fans (customers) or the interests of the association's decision makers? Does antitrust enforcement improve the functioning of the economy or distract from it? Again, Bob had answers.

Much of Bob's broader work in economics was unconventional, often turning analysis onto analysts. Consider: "Rates of Publication Per Faculty Member in Forty-Five 'Rated' Economics Departments" (1975), "Rent Seeking in Academia" (1980), "Life among the Triangles and Trapezoids" (1995), "Economists as the Subject of Economic Inquiry" (1986), "A Theory of Truth in Autobiography" (1986), "The Incentive to Cite" (1987), "The Half-Life of Dead Economists" (1989), and "Good Colleagues" (2003). ${ }^{1}$ The titles of some of his pieces are provocative, even entertaining. For examples: "Toenote to a Footnote" (1979), "Would Cows Vote Carnivore?" (1987), "Homo Basketballus" (1990), "The Shadow Price of Sunshine" (1991), "The Economics of Sin and Redemption: Purgatory as a Market-Pull Innovation” (1992), "Preaching Matters” (1993), “The Probability

\footnotetext{
1 Bob's co-authors are not identified here.
}

James C. Miller III

jim@jimmiller.org

1 Center for Study of Public Choice, George Mason University, Fairfax, VA, USA 
of Being President" (1993), "A Snipe Hunt" (2004), and "Regulators and Redskins" (2012). What serious student of economics would not be attracted to a professor with this breadth of interests and sense of humor?

Bob not only was a prolific researcher, but was incredibly generous to colleagues. Of the 13 books Bob lists in his c.v., every single one has one or more co-authors. Of the 22 edited collections, only three are without a co-editor. Of the 21 textbooks he lists (including multiple editions), none is without a co-author. More than half of his contributions to books (65 of 116, many of which were solicited and include numerous forwards, prefaces, and introductions, as well as brief comments and contributions to encyclopedias) are co-authored. Of Bob's 240 main papers, 220 of them are co-authored, as are 36 of his 53 notes, comments, and replies. If my experience is any guide, the major credit for a majority of these collaborative efforts goes to Bob Tollison.

Over the long term, Bob's major contribution may well be his nurturing of students. Consider that the first two of 49 dissertations he directed were by Mark Crain and Tom Deaton, both noted public choice scholars. The third was by Bobby McCormick, now Dean of the College of Business at Clemson, and the eighth was by Henry Butler, now Dean of the Scalia Law School at George Mason. In addition, Bob was a reader or director of 66 (other) dissertations and 36 theses.

Bob's nurturing didn't stop there. I know of numerous instances where Bob advised and promoted former students long after they had received their terminal degrees. Being one of "Bob's people" had tremendous cachet. Bob was called upon often for suggestions about personnel or recommendations about candidates. One of his favorite responses was "He's (or she's) a good man (or woman); hire him (or her)!" That recommendation from Bob usually was sufficient to generate a job offer.

Bob's generosity to colleagues extended beyond co-authorships. Countless times he engineered appointments, awards, consultancies, recognitions, and other favors, many times without the beneficiary's even knowing the source. Like many of you, I have been a recipient of Bob's largesse, and, like you, I am very grateful.

Let me conclude with a few personal recollections that illustrate what it was like to be around Bob Tollison.

In the early 1980s, through false and deceptive advertising (!), I was able to persuade Bob to take on the job of directing the Federal Trade Commission's Bureau of Economics. Every morning we'd have a senior staff meeting around a long table, with Bob at one end and me at the other. I'd opine about some notion and state my proposal. "Good reasoning, Mr. Chairman," would say one office head. "Very insightful," would say another. "Right on the mark," and so on. Until it got to Bob, who frequently would look up from some manuscript he was writing or editing and say, "Jim, you are full of s....!" Just shows the importance of having colleagues who will tell you when you are full of yourself.

Bob not only took over the Bureau of Economics, but agreed to serve as acting director of the FTC's Office of Policy Development. At one morning meeting I asked Bob, "How's the Office of Policy Development coming along?," to which he responded, "What Office? I abolished it." Now, there was a government official who knew how to subtract as well as to add!

Some people at the FTC took exception to Bob, since he was particularly critical of policies pursued by the previous administration. One holdover official was heard to complain, "Why, we now have a Director of the Bureau of Economics who drives a pickup truck to work." Correct-a Dodge truck.

While he was teaching at Texas A\&M, Bob rode a bicycle to and from campus. In a misguided effort to protect pedestrians, the campus police introduced a "law" prohibiting 
bicyclists from riding in open areas. When Bob was apprehended, he told the official that it was an "uneconomic law" because the costs of the law outweighed the benefits-and was let go.

Frequently, under Bob's leadership, the younger faculty members would meet with graduate students for a night of low-stakes poker. Bob christened this program "redistribution" - as from faculty to graduate students. Also, one of the prizes offered at a departmental social event was to "co-author a journal note or article with Bob Tollison."

Bob Tollison was a mentor to me as well as to hundreds of others for whom he was a cherished colleague, teacher, and friend. His legacy is huge and lasting. 